\title{
Schwannoma and Paraganglioma: Rare Causes of Pancoast Tumors with Increased FDG Uptake on PET/CT
}

\author{
${ }^{1}$ İnci Uslu Biner, ${ }^{2}$ Ebru Tatcı, ${ }^{1}$ Özlem Özmen, ${ }^{2}$ Ilke Bursalı \\ ${ }^{1}$ Ataturk Chest Diseases and Thoracic Surgery Training and Research Hospital, \\ Departments of Nuclear Medicine, Ankara \\ ${ }^{2}$ Ataturk Chest Diseases and Thoracic Surgery Training and Research Hospital, \\ Departments of Radiology, Ankara \\ email: inciuslu@yahoo.com
}

\begin{abstract}
Pancoast tumors are the masses that are located at the apical region of the lungs and may cause some typical symptoms, named as Pancoast Syndrome, like shoulder and arm pain, Horner's syndrome (ipsilateral ptosis, myosis, enophthalmus and anhydrosis) and weakness in ipsilateral hand musculature due to the invasion of the adjacent nerves and bone. These tumors are commonly the malign lung carcinomas. Here we report two cases of patients suffering from back and arm pain and that have some pancoast syndrome symptoms mentioned above, related to apical mass in radiological images. One of these patients had ptosis and anhydrosis associated with Horner's syndrome. 2-Deoxy-2-[18F] Fluoro-D-Glucose (FDG) with positron emission tomography/computerized tomography (PET/CT)was performed because of a suspicion of malignancy and an intense FDG accumulation was seen coincident with the apical tumor in both. The patients then underwent complete surgical resection of the mass and the masses were postoperatively diagnosed as paraganglioma and schwannoma, respectively. So, we wanted to emphasize that neurogenic tumors should be included in the differential diagnosis of Pancoast tumor as a rare cause and to remind the clinicians to give their attentions for essentiality of tissue diagnosis of Pancoast carcinoma before starting the treatment.
\end{abstract}

KEYWORDS: Pancoast tumor, neurogenic tumors, schwannoma, paraganglioma, PET/CT

\section{PET/CT GÖRÜNTÜLEMEDE ARTMIŞ FDG TUTULUMU GÖSTEREN NADIR PANKOAST TÜMÖRÜ NEDENLERINDEN SCHWANNOMA AND PARAGANGLIOMA}

ÖZET: Pankoast tümörleri omuz ve kol ağrısı, Horner Sendromu (ipsilateral ptozis, myozis, enoftalmus ve anhidrozis ) ve komşu sinir ve kemik yapılarının invazyonuna bağlı aynı taraf el kaslarında güçsüzlük gibi bazı tipik semptomlara, Pankoast Sendromu olarak isimlendirilir, neden olabilen akciğerlerin apikal kesimlerinde yerleşim gösteren kitlelerdir. Biz burada radyolojik görüntülemelerinde apikal kitlesiyle ilişkli sırt ve kol ağrısı tarifleyen ve yukarıda belirtilen bazı pankoast sendromu bulguları mevcut olan iki vakayı bildirdik. Hastalardan birisinin Horner Sendromuı ile ilişkili ptozis ve anhidrozisi vardı. İki olguda da 2-Deoxy-2-[18F] Fluoro-DGlucose (FDG) with positron emission tomography/computerized tomography (PET/CT) malignite şüphesiyle yapıldı ve apikal yerleşimli kitlelerde yoğun artmış FDG akümülasyonu izlendi. Hastalar opere edildi ve çıkarılan kitleler paraganglioma ve schwannoma olarak raporlandı. Bu olgularla nörojenik tümörlerin Pankoast tümörleri ayırıcı tanısında nadir nedenler arasında akılda bulundurulması gerektiğini vurgulamak ve Pankoast karsinomunun tedavisine başlamadan önce doku tanısının gerekliliği konusunu klinisyenlere hatırlatmak istedik..

ANAHTAR KELIMELER: Pankoast tümörü , nörojenik tümörler, schwannoma, paraganglioma, $\mathrm{PET} / \mathrm{CT}$ 



\section{Introduction}

Tumors located at lung apex near the thoracic inlet are regarded as pancoast tumors. That may cause shoulder and arm pain, Horner's syndrome (ipsilateral ptosis, myosis, enophthalmus and anhydrosis caused by the invasion of the paravertebral symphatic chain and the inferior cervical ganglion), and weakness in ipsilateral hand muscles. Pancoast syndrome is a sum of some typical symptoms as explained above. This syndrome is commonly reported in malign apical lung carcinomas but rarely in conditions including neurogenic tumors, pleural mesothelioma, infectious and inflammatory lung diseases and vascular lesions [1]. Schwannoma and paragangliomas are neurogenic tumors usually located at posterior mediastinal region in thorax. Schwannoma, mostly seen type of the neurogenic tumors, generally originate from the schwann cells and usually benign and asymptomatic. They mostly discovered incidentally on routine chest radiography [2,3]. Paragangliomas are the neurogenic tumors derivate from either cromaffin sympathetic paraganglia cells (adrenal and extra-adrenal ) or parasympathetic (head and neck) paraganglia. They may be functional (due to catecholamine secretion) or nonfunctional so asymptomatic. The cause of hypertension and other symptoms like headache, palpitation, sweats and tremor can be often functional mediastinal paragangliomas $[4,5]$. In the assessment of the mediastinal neurogenic tumors primary diagnostic modality is Chest computed tomography (CT) but magnetic resonance imaging (MRI) is also useful to determine intraspinal extension [6].

This report presents two cases of neurogenic tumors located at the lung apex; diagnosed as schwannoma and paraganglioma respectively as rare causes of the Pancoast tumors .

\section{Case reports}

\section{Case 1}

A previously healthy 23-year-old female was admitted to our hospital with a history of some symptoms of Horner's syndrome like pitosis, unhydrosis. Additionally, she has been suffering from back pain and weakness of right arm for 9 months. Chest CT showed a mass at apical paravertebral localization of the right lung measuring $38 \times 26 \times 34 \mathrm{~mm}$. The right apical mass showed focal increased FDG accumulation (maximum standardized uptake value [SUV max] 5.9) on FDG-PET/CT.

MRI demonstrated the mass apical mass was hypointense in T1-weighted images and hyperintense in $\mathrm{T} 2$-weighted images with a huge contrast uptake after contrast injection. Although, the mass was close to the neural foramen at T3-T4 level and the spinal cord was intact. Transthoracic fine needle aspiration biopsy was performed and the histopathology was reported as neurogenic tumor. For certain diagnosis, complete surgical resection of the mass through right thoracotomy was performed and final pathologic diagnosis was paraganglioma. A connection of nerve through the T2-3 intercostal area was seen intraoperatively.

\section{Case 2}

A previously healthy 26-year-old male with no significant past medical history, was admitted to our hospital with a history of left arm, back pain and left proximal arm edema. Chest CT images revealed a mass measuring $52 \times 65 \mathrm{~mm}$ at left lung apical region and paravertebral localization. FDG-PET/BT scan showed focal increased FDG uptake (SUV max: 6.29) consistent with tumor. There was no evidence of local and distant metastasis. MRI showed a mass at same region which is close to the left subclavian artery. But there was no invasion of vascular or other surrounding tissues. Transthoracic fine needle aspiration biopsy reported as peripheral nerve shield tumor. Complete surgical resection of paravertebral mass through left thoracotomy was performed and final pathologic diagnosis was Schwannoma.

\section{Discussion}

Neurogenic tumors arise from cells of the nerve sheath, paraganglionic tissue, and autonomic ganglia. Schwannoma arise from Schwann cells of the nerve sheath. Paragangliomas derivate from either cromaffin sympathetic paraganglia cells (adrenal and extra-adrenal) or parasympathetic (head and neck) paraganglia. Mediastinal neurogenic tumors are commonly situated in the posterior costovertebral sulcus or in the chest wall [7]. When neurogenic tumors are located at the upper thoracic 
paravertebral region, it may extent the ipsilateral pulmonary apex and cause to Horner's syndrome [8]. The differential diagnosis of apical neurogenic tumors from Pancoast carcinoma is important. Pancoast carcinomas are aggressive apical lung tumors with poor prognosis due to late diagnosis because of their nonspecific symptoms. On the other hand, treatment of the Pancoast tumors has some difficulties than other lung cancers due to their unique properties originating from their anatomic localizations. ACCP and NCCN guidelines advised induction chemo-radiotherapy followed by resection for the treatment of Pancoast carcinomas $[9,10]$. The mortality rate of this kind of multimodality therapies ranges from $1.3 \%$ to $2.7 \%[11,12]$. It is important to make differential diagnosis of the Pancoast carcinoma from other rare conditions that are located in the lung apex that can cause similar appearance and symptoms. Sarkar A. et al reported a case showing similar Pancoast Syndrome symptoms due to non-Hodgkin's lymphoma [13]. Although this lesion is malignant, the treatment approach is completely different. Dao I. Et al also mentioned about cyst hydatic as a rare cause of pancoast syndrome [14].
Pancoast syndrome can rarely be associated with neurogenic tumors located in pulmonary apex. Here we reported two histopathologically different neurogenic tumors diagnosed as paraganglioma and schwannoma as a rare cause of Pancoast tumor. Variable degree of increased FDG uptake in benign and recurrent malign schwannomas that is independent from cellular origin has been reported in previous reports [15]. On the other hand, intensity of FDG uptake increases corresponding with its malignant potential and presence of a mutation of succinate dehydrogenase in paragangliomas [16].

We present two cases of benign neurogenic tumors that clinically cause Pancoast syndrome showing increased FDG uptake. Histopathological confirmation is needed for accurate diagnosis in FDG avid apical pulmonary lesions. So, the authors would like to remind the clinicians to give their attentions for essentiality of preoperative tissue diagnosis before starting the treatments.

Conflict of interest:The authors declare no conflict of interest

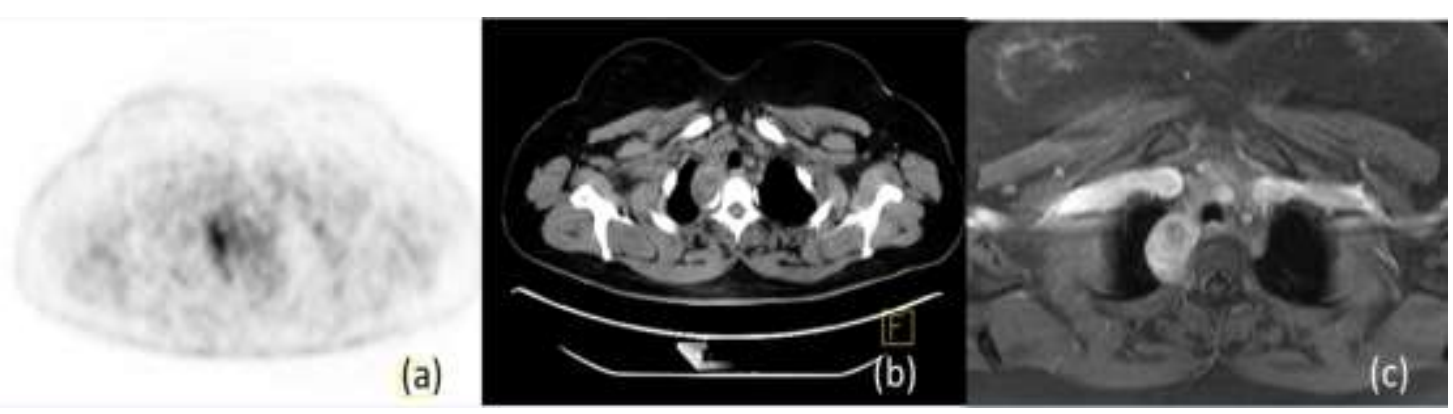

Figure 1. (a) PET/CT showed focal increased FDG accumulation (SUV max: 5.9) consistent with the right apical tumor. (b) Chest CT shows an isodense apical mass of the right lung. (c) Axial T2-weighted chest MRI image of contrast-enhanced, heterogeneous hyperintense mass at the right mediastinum that begins at T1 level and lies to the level of T3vertebra was noted. 

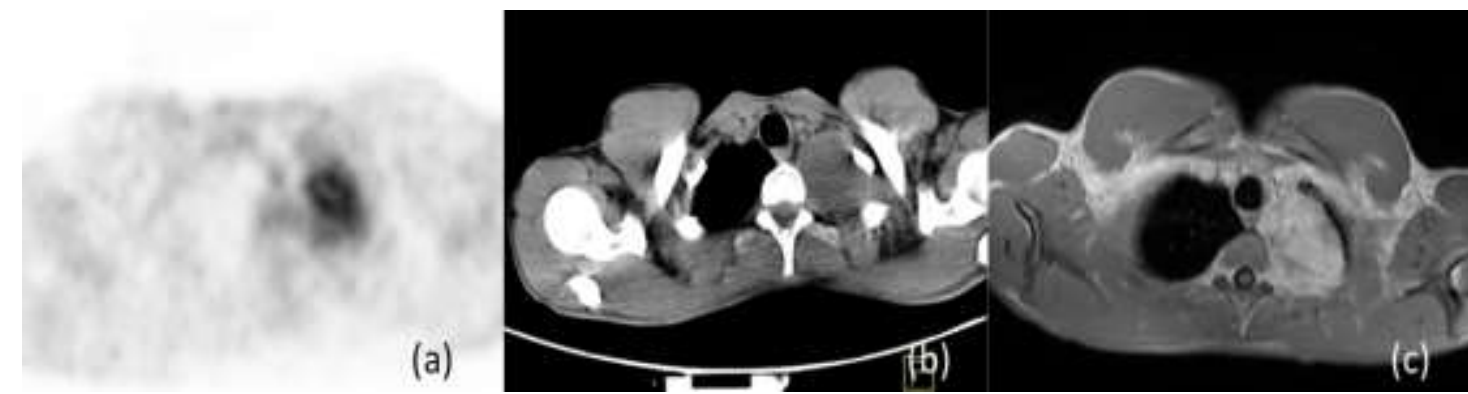

Figure 2. (a) PET/CT showed focal increased FDG accumulation (SUV max: 6.2) consistent with the left apical tumor. $(b)$ Chest $C T$ showed a heterogeneous hypo dense mass at apical region of the right lung (c). A chest MRI was performed and showed a mass at left lung apical and at paravertebral localization close to the left subclavian artery. Axiel T2-weighted MRI image of contrast-enhanced, heterogeneous hyper intense mass at the right lung apex was noted

\section{REFERENCES}

1. Arcasoy, S. M., \& Jett, J. R. (1997). Superior pulmonary sulcus tumors and Pancoast's syndrome. New England Journal of Medicine, 337(19), 1370-1376.

2. Khanlou, H., Khanlou, N., \& Eiger, G. (1998). Schwannoma of posterior mediastinum: a case report and concise review. Heart \& Lung: The Journal of Acute and Critical Care, 27(5), 344-347.

3. Topcu, S., Alper, A., Gülhan, E., Kocyigit, O., Tastepe, I., \& Cetin, G. (1999). Neurogenic tumours of the mediastinum: a report of 60 cases. Canadian respiratory journal: journal of the Canadian Thoracic Society, 7(3), 261-265.

4. Young, W. F. (2006). Paragangliomas. Annals of the New York Academy of Sciences, 1073(1), 21-29.

5. Balcombe, J., Torigian, D. A., Kim, W., \& Miller Jr, W. T. (2007). Cross-sectional imaging of paragangliomas of the aortic body and other thoracic branchiomeric paraganglia. American Journal of Roentgenology, 188(4), 1054-1058.

6. Naidich, D. P, Webb R, Mueller NL, (eds). (2000). The Mediastinum. In: Computed Tomography and Magnetic Resonance of the Thorax, 3rd edn. New York: Lippincott Williams and Wilkins., pp 134159.

7. Yamaguchi, M., Yoshino, I., Fukuyama, S., Osoegawa, A., Kameyama, T., Tagawa, T., \& Maehara, Y. (2004). Surgical treatment of neurogenic tumors of the chest. Annals of thoracic and cardiovascular surgery, 10(3), 148-151.

8. Bošnjak, R., Bačovnik, U., Podnar, S., \& Benedičič, M. (2007). T1-nerve root neuroma presenting with apical mass and Horner's syndrome. Journal of brachial plexus and peripheral nerve injury, 2(1), 7.

9. Shen, K. R., Meyers, B. F., Larner, J. M., \& Jones, D. R. (2007). Special treatment issues in lung cancer: ACCP evidence-based clinical practice guidelines. CHEST Journal, 132(3_suppl), 290S$305 \mathrm{~S}$.

10. Ettinger, D. S., Akerley, W., Bepler, G., Blum, M. G., Chang, A., Cheney, R. T., \& Govindan, R.
NCCN Clinical Practice Guidelines in Oncology: Non-Small Cell Lung Cancer. 2012: V2.

11. Rusch, V. W., Giroux, D. J., Kraut, M. J., Crowley, J., Hazuka, M., Winton, T., \& Livingston, R. B. (2007). Induction chemoradiation and surgical resection for superior sulcus non-small-cell lung carcinomas: Long-term results of Southwest Oncology Group trial 9416 (Intergroup Trial 0160). Journal of Clinical Oncology, 25(3), 313318.

12. Kunitoh, H., Kato, H., Tsuboi, M., Shibata, T., Asamura, H., Ichonose, Y., \& Nakagawa, K. (2008). Phase II trial of preoperative chemoradiotherapy followed by surgical resection in patients with superior sulcus non-small-cell lung cancers: report of Japan Clinical Oncology Group trial 9806. Journal of Clinical Oncology, 26(4), 644-649.

13. Sarkar, A., Das, A., Basuthakur, S., Pandit, S., Das, S. K., \& Choudhury, S. (2013). Pancoast syndrome: A rare presentation of non-Hodgkin's lymphoma.Lung India: official organ of Indian Chest Society, 30(3), 209.

14. Dao, I., El Mostarchid, B., Onen, J., Mandour, C., El Asri, C. A., \& Boucetta, M. (2013). Pancaost syndrome related to hydatid cyst. The Pan African medical journal, 14.

15. Halac, M., Cnaral, F., Sait, S., Ylmaz, S., Kerim, S., Sergülen, D., \& Uslu, I. (2008). FDG PET/CT findings in recurrent malignant schwannoma. Clinical nuclear medicine,33(3), 172-174.

16. King, K. S., Chen, C. C., Alexopoulos, D. K., Whatley, M. A., Reynolds, J. C., Patronas, N., \& Stratakis, C. A. (2011). Functional imaging of SDHx-related head and neck paragangliomas: comparison of $18 \mathrm{~F}$-fluorodihydroxyphenylalanine, 18F-fluorodopamine, 18F-fluoro-2-deoxy-Dglucose PET, 123I-metaiodobenzylguanidine scintigraphy, and 111In-pentetreotide scintigraphy. The Journal of Clinical Endocrinology \& Metabolism, 96(9), 2779-2785. 